\title{
Fundamental Motor Skill among 6-Year-Old Children in Padang, West Sumatera, Indonesia
}

\author{
Syahrial Bakhtiar ${ }^{1}$ \\ ${ }^{1}$ Faculty of Sports Science, Universitas Negeri Padang, Indonesia \\ Correspondence: Syahrial Bakhtiar, Vice Rector of Students Affairs, Universitas Negeri Padang, Jl. Prof. Dr. \\ Hamka - Air Tawar, Padang, Sumatera Barat, Indonesia. E-mail: syal_fik@yahoo.com
}

Received: February 12, 2014 Accepted: February 20, 2014 Online Published: February 28, 2014

doi:10.5539/ass.v10n5p155 URL: http://dx.doi.org/10.5539/ass.v10n5p155

\begin{abstract}
This study examined 6 year-old children's fundamental motor skills. Participants were 67 first grade elementary students in rural and urban area in Padang, West Sumatera, Indonesia. All participants were evaluated with the Test of Gross Motor Development-2 (TGMD-2) (Ulrich, 2000). Boys were slightly higher in both locomotor and manipulative skills, yet there were no gender differences for both skills. Children in the average fundamental motor skills group is more in the rural area as compared to urban areas. Urban area children with advance fundamental skills development is lower than the numbers with average fundamental motor skills development. It is suggested that a larger scale of study should be conducted to get a baseline data about Indonesian children motor proficiency.
\end{abstract}

Keywords: fundamental motor skill, children, Indonesia

\section{Introduction}

Fundamental motor skills are the basic pattern of movements to support more complex movement in sports and daily activities. Research has shown the essential of fundamental motor skills for children in relation to be physically active throughout their life (Cools, Martelaer, Samaey \& Andries, 2011; Fisher, Reilly, Kelly, Montgomery, Williamson, Paton \& Grant, 2005; Williams, Pfeiffer \& O'neill, 2008). Hence, different motor development program for children have been created and implemented with various pedagogical approaches, such as direct instructional approach (Draper, Achmat, Forbes \& Lambert, 2012; Golos, et al., 2011; Graf, et al., 2008), mastery motivational approach (Robinson, 2011; Robinson \& Goodway, 2009; Martin, Rudisill \& Hastie, 2009) and music - movement program (Deli, Bakle \& Zachopoulou, 2006; Venetsanou \& Kambas, 2004). All of these program showed evidences that motor development program successfully improved children's fundamental motor skills from being delayed in motor development to being atypical in motor development related to their age.

During the last decade, studies about motor skills among children has been conducted in countries such as Australia, England, United States of America, Belgium, Scotland, South America and Asia. Hardy, King, Farrel, Macniven, and Howlett (2010) assessed motor skills of 330 preschoolers (171 boys and 159 girls) in the Sydney area of New South Wales (NSW), Australia and concluded that most children were developmentally delayed in their motor skills with no gender differences. Running was the most proficiency skills among Australian children while striking was the least proficient skills. While Goodway, Robinson, and Crowe (2010) examined children in the southwest and midwest of America and found that boys are significantly better in manipulative skills than girls, even though all participants were developmentally delayed in fundamental motor skills.

Data about fundamental motor skills among children, either preschool or elementary school children, in Indonesia is limited due to the lack of understanding about this discipline in Indonesia. Some empirical evidences inspired educators to develop and implement motor development program for Indonesian children. However, to design an appropriate program for children, it is important to know the mastery level of children in fundamental motor skills. Knowing the limited information about children's proficiency in motor skills in Indonesia, the purpose of this study was to investigate the basic description of children's motor skill proficiency in Indonesia. Since this is a preliminary investigation, this study was conducted in a smaller scale in Padang, West Sumatera, involving rural and urban elementary schools, with expectations that this study would guide other researchers to conduct a similar study at the national level. The reason for choosing elementary school 
students instead of preschool children was because preschool is a new educational system in Indonesia and is not fully practiced across Indonesia. Thus, examining younger elementary school students is considered more beneficial.

\section{Methods}

Since this study was a preliminary study, sampling should generally represent the demography of Indonesia, especially in educational distribution. The demographic diversity in Padang reflects the diversity in Indonesia. Hence the study population was all elementary school students of Padang. Samples were chosen using multi-stage random sampling involving several stages. The first stage is chosing the sampling area (school location) in the cluster. The second stage is determining the number of respondents based on age and gender using proportional random sampling. The sample were selected from the youngest age of elementary school children, which is about 6 to 7 years old, consisting of 67 children, which proportionally represented the population of children in that age group in rural and urban area of Padang. The samples were then divided into two groups, namely rural and urban group.

Data of children proficiency in motor skill was collected using TGMD-2 introduced by Ulrich (2000). This assessment was selected to measure the ability of fundamental motor skills because of its proven validity and reliability. TGMD-2 evaluates children mastery in locomotor skills (running, galloping, hopping, leaping, horizontal jump, and, sliding) manipulative skills (striking, stationary dribbling, catching, kicking, overhand throw, and, underhand roll).

Data were analyzed by descriptively and proportionally to depict the basic profile of fundamental motor skills proficiency of elementary school children in Padang. Independent t-test was also used to determine the differences between girls and boys for both locomotor and manipulative skills.

\section{Results}

Sixty seven grade one elementary school children aged between 6.08 to 6.92 years (mean 6.55 years; $\mathrm{SD} \pm 0.25$ ) were involved in this study, consisting of 23 children (12 boys and 11 girls) were studying in rural area and 44 children ( 16 boys and 28 girls) were in the urban area. This proportion was based on the distribution of schools and demography of the population in Padang, where urban has more population and schools than rural area.

The result shows that boys' locomotor skill $(M=39.21, S D=5.28)$ is higher than girls' $(M=35.92, S D=8.17)$. However, there is no significant gender difference between boys and girls in locomotor skills $(\mathrm{t}(65)=3.291$, $\mathrm{p}>.05)$. As for the manipulative skills. boys manipulative ability $(\mathrm{M}=37.57, \mathrm{SD}=7.48)$ is slightly higher than girls $(\mathrm{M}=35.59, \mathrm{SD}=6.29)$. This difference is also not significant $\mathrm{t}(65)=1.982, \mathrm{p}>$.05. Since samples were drawn from two different regions, the rural and urban, the profile of children proficiency in motor skills was slightly different between both regions. More children in rural area were average for both locomotor and manipulative skills. Children with delayed motor skill ability in the rural area were $4 \%$ higher than in the urban area. In contrast, over $17 \%$ of children in urban area has advance motor skills as compared to those in the rural area (Figure1).

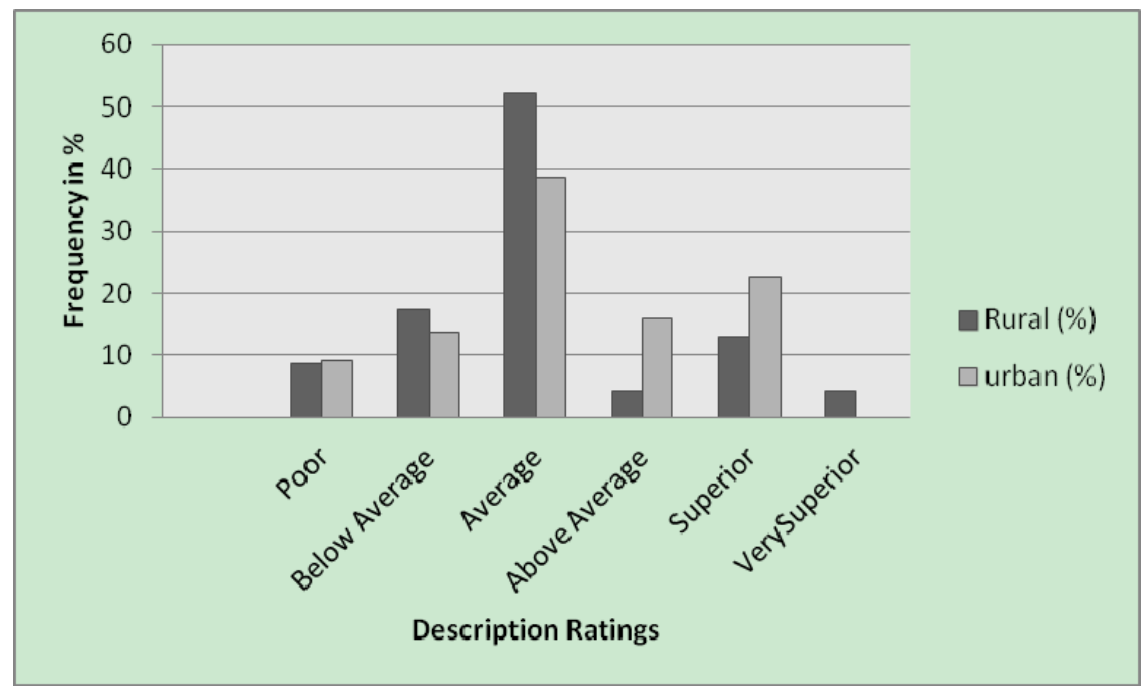

Figure 1. Comparison of motor proficiency of children in rural and urban region based on TGMD-2 ratings 
The profile of both boys' and girls' ability in fundamental motor skills between rural and urban area was slightly similar. Both boys and girls with average proficiency in motor skills were higher in the rural area than the urban area. However, children who had advance skills were more in the urban area compared to those in the rural area.

\section{Discussion}

The findings from this study showed that the proficiency of elementary school children age 6-year-old in Indonesia had a different tendency across the gender and region compared to previous researches. Boys were more skillful than girls for locomotor skill in both region, although there is no significant gender differences, while in New South Wales, Australia, Hardy, King, Farrel, Macniven and Howlett (2010) found that girls had higher locomotor skills than boys. However, this difference was not significant. This finding is similar to the findings of Goodway, Robinson and Crowe (2010) suggesting that there are no gender differences for locomotor skills in children.

This study also found that boys were slightly higher in manipulative skills than girls. This finding is similar to that of Hardy et.al. (2010). Both Hardy and friends' and this study found that there are no gender differences in manipulative skills. On the other hand, Goodway, Robinson and Crowe (2010) found that boys were significantly higher in manipulative skills than girls. It means that there is gender difference in manipulative skills for children.

The variety in results reflects that every country has different level of mastery for children's motor skills proficiency. This condition is based on many factors, such as the geographical contour, culture of the society, safety issues as well as nutrition. This evidence reveals that one motor skill program would not be suitable for all children around the world. A motor skill program must be appropriately designed for children specific to their needs, region and country.

Another key point is more children in rural area had average proficiency in motor skills than children in urban area. This may be due to the circumstance in rural areas where accessible transportation and technology is rather limited than urban areas. Thus, children walk to school instead of being driven, or play outside instead of play in the front of a monitor. In other words, children in rural areas are more physically active than urban area children. However, it is interesting that for children who had above average and superior motor skill were higher in urban than rural areas. This might be explained by the availability of supporting facilities for children in urban areas to do physical activity is more and easily accessible than the rural areas. Under these circumstances, children who choose to be physically active, they have various options to choose and prevent them from being bored. These, in turn will gradually improve their motor skills.

Overall, the findings in this study reveal some facts that many children were delayed in their motor skills. This information showed that Indonesia do need to pay more attention to this phenomenon. This initial data showed that different region influences children motor skills. Based on this finding, it is essential to do a larger scale, even a national scale assessment for children's motor skills with a larger sample size and different age group in order to be able to design a developmentally appropriate motor skill program for children. The mastery of fundamental motor skills for children is not only beneficial for them during childhood, but also helpful for them during middle and high school to learn about sport related movement. Furthermore, fundamental motor skills promote children to be physically active throughout their life and to be actively engaged in sports.

\section{Conclusion}

Fundamental motor skill is a basic movement for children that should be mastered during childhood. These skills should be taught properly, so knowing children basic level in their skills is an essential foundation to design an appropriate motor development program for children and propose national policies that are valuable not only for children, but also for the society and nation. For this reason, it is suggested that a larger scale of assessment of children's motor skill in Indonesia should be conducted, so Indonesia can compete with other country in developing children to be healthier and competence to face global challenges.

\section{References}

Cools, W., De, M. K., Samaey, C., \& Andries, C. (2011). Fundamental movement skill performance of preschool children in relation to family context. Journal of Sports Sciences, 29(7), 649-660. http://dx.doi.org/10.1080/02640414.2010.551540

Deli, E., Bakle, I., \& Zachopoulou, E. (2006).Implementing intervention movement programs for kindergarten children. Journal of Early Childhood Research, 4(1), 5-18. http://dx.doi.org/10.1177/1476718X06059785 
Draper, C. E., Achmat, M., Forbes, J., \& Lambert, E. V. (2012). Impact of a community-based programme for motor development on gross motor skills and cognitive function in preschool children from disadvantaged settings. Early Child Development and Care, 182(1), 137-152. http://dx.doi.org/10.1080/03004430.2010.547250

Fisher, A., Reilly, J. J., Kelly, L. A., Montgomery, C., Williamson, A., Paton, J. Y., \& Grant, S. (2005). Fundamental movement skills and habitual physical activity in young children. Medicine and Science in Sports and Exercise, 37(4), 684-688. http://dx.doi.org/10.1249/01.MSS.0000159138.48107.7D

Golos, A., Sarid, M., Weill, M., \& Weintraub, N. (2011). Efficacy of an early intervention program for at-risk preschool boys: A two-group control study. The American Journal of Occupational Therapy, 65(4), 400-408. http://dx.doi.org/10.5014/ajot.2011.000455

Goodway, J. D., Robinson, L. E., \& Crowe, H. (2010, January 1). Gender differences in fundamental motor skill development in disadvantaged preschoolers from two geographical regions. Research Quarterly for Exercise and Sport, 81(1), 17-24. http://dx.doi.org/10.1080/02701367.2010.10599624

Graf, C., Koch, B., Falkowski, G., Jouck, S., Christ, H., Staudenmaier, K., \& Dordel, S. (2008). School-based prevention: Effects on obesity and physical performance after 4 years. Journal of Sports Sciences, 26(10), 987-994. http://dx.doi.org/10.1080/02640410801930176

Hardy, L. L., King, L., Farrell, L., Macniven, R., \& Howlett, S. (2010). Fundamental movement skills among Australian preschool children. Journal of Science and Medicine in Sport, 13(5), 503-508. http://dx.doi.org/10.1016/j.jsams.2009.05.010

Martin, E. H., Rudisill, M. E., \& Hastie, P. A. (2009). Motivational climate and fundamental motor skill performance in a naturalistic physical education setting. Physical Education \& Sport Pedagogy, 14(3), 227-240. http://dx.doi.org/10.1080/17408980801974952

Robinson, L. E. (2011). Effect of a mastery climate motor program on object control skills and perceived physical competence in preschoolers. Research Quarterly for Exercise \& Sport, 82(2), 355-359. http://dx.doi.org/10.1080/02701367.2011.10599764

Robinson, L. E., \& Goodway, J. D. (2009). Instructional climates in. preschool children who are at-risk.part I: Object-control skill development. Research Quarterly for Exercise \& Sport, 80(3), 533-542.

Ulrich, D. A. (2000). The Test of Gross Motor Development (2nd ed.). PRO-ED, Austin, TX, USA.

Venetsanou, F., \& Kambas, A. (2004). How can a traditional greek dances programme affect the motor proficiency of pre-school children? Research in Dance Education, 5(2), 127-138. http://dx.doi.org/10.1080/14617890500064019

Williams, H. G., Pfeiffer, K. A., O'Neill, J. R., Dowda, M., McIver, K. L., Brown, W. H., \& Pate, R. R. (2008). Motor skill performance and physical activity in preschool children. Obesity (silver Spring, Md.), 16(6), 1421-1426. http://dx.doi.org/10.1038/oby.2008.214

\section{Copyrights}

Copyright for this article is retained by the author(s), with first publication rights granted to the journal.

This is an open-access article distributed under the terms and conditions of the Creative Commons Attribution license (http://creativecommons.org/licenses/by/3.0/). 